\title{
COMPARATIVE TOXICITIES OF THREE INSECTICIDES ON EGGS HATCHABILITY OF Pectinophora gossypiella (SAUNDERS) AND Earias insulana (BOISD.) AND THEIR SIDE EFFECTS ON WASPS OF Trichogramma SPP. (HYMENOPTERA: TRICHOGRAMMATIDAE), UNDER LABORATORY CONDITIONS \\ Manal A. A. El Sharkawy \\ Plant Protection Research Institute, ARC, Dokki Egypt
}

\begin{abstract}
Studies on the toxicity of some new insecticides against Pectinophora gossypiella (Saunders) and Earias insulana (Boisd.) eggs were carried out under laboratory conditions. Field Recommended concentrations (FRCs) of three insecticides viz., Trebon (Etofenprox 30\% EC), Cygron (Alpha-Cypermethrin 7\% + Flufenoxuron 3\% EC), and Raner (Methoxyfenozide 24 SC \%) were tested against both eggs of PBW \& SBW. Also, persistent toxicity of the tested insecticides was determined against the most susceptible life stage (adult) of three wasps of egg Parasitoid Trichogramma spp., Trichogramma evanescens, Trichogrammatoidea bactrae and Trichogramma brassicae. Results regarding the harmful effects of the insecticides on eggs hatchability of PBW revealed that Trebon caused the highest percentage of mortality $(95.52 \%)$ followed by Cygron treatment $(93.39 \%)$, while Raner caused the less percentage of egg mortality $(22.35 \%)$. There were insignificant differences between mortality percentages caused by insecticides (Trebon\& Cygron) and which obtained by Trichogramma evanescens (90.61\%). In case of SBW, Trebon caused the highest percentage of mortality $(78.7 \%)$ followed by Cygron $(67.5 \%)$ and Raner was the least effective $(32.82 \%)$ whereas, eggs mortality caused by Trichogramma spp. ranged between $(65.72-75.1 \%)$ with no differences than those caused by Trebon\& Cygron as in case of PBW. On the other hand, Trebon and Cygron showed a strong impact on the tested parasitoids, in contrast Raner was the least one on the tested parasitoids. Regardless of used insecticides, $T$. evanescens achieved the highest percentage of parasitism (46.53\%) compared to $28.82 \& 20.31 \%$ for $T$. bactrae and $T$. brassicae, respectively, whereas, percentage of adult emergence did not differ significantly between the three species of Trichogramma.

On the basis of this study, it could be concluded that Trebon and Cygron proved highly toxic to the tested pests and showed a strong impact on the tested parasitoids and could not therefore be used in combination with Trichogramma releases, whereas, Raner, is considerably mildly toxic for the pests and less harm for the bio-control agents.
\end{abstract}

Keywords: Insecticides, egg parasitoids,Trichogramma spp., PBW, Pectinophora gossypiella, SBW, Earias insulana.

\section{INTRODUCTION}

The pink bollworm, Pectinophora gossypiella and spiny bollworm Earias insulana are considered the most injurious cotton pests. The larvae feed on flower buds, flowers, bolls and the seeds within to developing seeds, and cause damage by reducing the yield and staple length. Chemical control using synthetic insecticides is the primary method to manage those pests, but 
it has serious drawbacks, including wildlife losses, destruction of natural enemies, crop pollination problems and the development of pesticide resistance in pests (David Pimentel, 2005).

One major purpose of Integrated Pest Management (IPM) strategies is to unify the safe and sustainable use of chemical and biological control methods. Therefore, the side-effects of pesticides on bio control agents should be carefully evaluated for induction in IPM programs (Stark et al., 2007). The management of insect pests can be optimized by methods of control not antagonistic to the beneficial organisms (Degrande et al. 2002\& Devotto et al. 2008). Trichogrammatid egg parasitoids are considered to be the most useful biological control agents for inundative releases against lepidopterous pests (Singh and Jalali 1994). Therefore, it is imperative to assess its compatibility with chemical control for induction in integrated pest management programs. Wasps of the genus Trichogramma have several advantages as biological control agents, including relative ease of rearing and fact that they kill their host in the egg stage before it causes feeding damage (Bigler, 1984). Releases of Trichogramma are successfully used on large scale on corn, cotton, sugarcane, fruit tree and vegetable crops in more than 50 countries (Smith 1996 and Antoon et al. 2006). In Egypt, T. evanescens has been used successfully since 1984 as a biocontrol agent against different insect pests; the sugar-cane borer, Chilo agamenon on sugar-cane and rice, the olive pest Prays oleae, the peach bud borer, Anarsia lineatella on peach and apricot, the grape-fruit worm, Lopezia botrana and the date fruit worms, Ephestia spp. on date palms (Abbas, 2004). Augmentative releases of Trichogramma can be affected by the use of broadspectrum insecticides in or near release plots (King et al. 1984). In India, Tuhan et al. (1987) found that application of Trichogramma brasiliense in combination with chemical insecticides gave good control of pink bollworm.

The present laboratory study was conducted to investigate three objectives: the first to study the impact of three insecticides on hatchability of $P$. gossypiella and $E$. insulana eggs to determine the percentage of eggs mortality and compare it with that obtained by egg parasitoids Trichogramma ssp. The second to determine the side-effect of the three tested insecticides on the susceptible life stage (adults) of three Trichogramma species by exposing the adults to the different treatments, and inspect females' longevity, percentage of parasitism and adults' emergence. The third target was to compare the three species of Trichogramma and constricting whichever less effected to insecticides treatments to investigate the possibility of using these insecticides in sequence with Trichogramma.

\section{MATERIALS AND METHODS}

The present experiments were carried out in Bollworms Department (Trichogrammatid Laboratory), Plant protection Research Institute, ARC, Dokki, Giza, Egypt.

Insecticides used:

All tests were conducted with fresh solutions of three commercial insecticides prepared in distilled water; the field recommended concentration 
for each insecticide was used. The trade, common names and recommended field applications rates are summarized in Table (1).

Rearing of $P$. gossypiella and $E$. insulana:

Newly hatched larvae of $P$. gossypiella and Earias insulana were obtained from a colony maintained in the Bollworms Department Laboratory, Plant Protection Research Institute, Ministry of Agriculture, Dokki, Giza for several generations at $\left(27 \pm 1^{\circ} \mathrm{C} \& 75 \pm 5 \% \mathrm{RH}\right)$. Larvae were reared on a modified artificial diet as described previously by Abd El-Hafez et al. (1982).

Table (1): Technical specifications of the experimental insecticides.

\begin{tabular}{|c|c|c|c|c|}
\hline $\begin{array}{l}\text { Trade } \\
\text { name }\end{array}$ & $\begin{array}{c}\text { Common } \\
\text { name }\end{array}$ & Formulations & Active components & Dosage* \\
\hline Trebon & Etofenprox & $30 \% \mathrm{EC}$ & $\begin{array}{l}\text { 2-(4-ethoxyphenyl)- } \\
\text { 2-methylpropyl } \\
\text { 3-phenoxybenzyl ether. }\end{array}$ & $\begin{array}{c}250 \\
\mathrm{~cm}^{3} / \text { feddan }\end{array}$ \\
\hline Cygron & \begin{tabular}{|l|} 
Alpha- \\
Cypermethrin- \\
Flufenoxuron
\end{tabular} & $10 \% \mathrm{EC}$ & $\begin{array}{c}\text { Alpha-cypermethrin7\%: } \\
\text { Aracemat comprising (S)-á- } \\
\text { cyano-3-phenoxybenzyl (1R, } \\
\text { 3R)-3-(2,2-dichloro viyl)-2,2- } \\
\text { dimethylcyclopropanecarboxylat } \\
\text { e and (R)- à-cyano -3- } \\
\text { phenoxybenzyl (1S, 3S)-3-(2,2- } \\
\text { dichloro vinyl)-2,2- } \\
\text { imethylcyclopropanecarboxylate. } \\
\text { Flufenoxuron3\%: 1-(4-(2-chloro- } \\
\text { ạ ạ, ạ-trifluoro-p-tolyl oxy)-2- } \\
\text { flucrophenyl-3-(2,6- } \\
\text { difluorobenzoyl)urea } \\
\end{array}$ & $\begin{array}{c}250 \\
\mathrm{~cm}^{3} / \text { feddan }\end{array}$ \\
\hline Raner & Methoxyfenozide & $24 \mathrm{SC} \%$ & $\begin{array}{l}\text { N-tert-butyl-N1-(3-methoxy-o- } \\
\text { toluoyl)-3,5-xylohydrazide) }\end{array}$ & $\begin{array}{c}37.5 \\
\mathrm{~cm} 3 / 100 \mathrm{~L} \\
\text { water }\end{array}$ \\
\hline
\end{tabular}

${ }^{\text {* }}$ Recommended dose/feddan in 400 Liter water.

\section{For obtaining eggs of $P$. gossypiella and $E$. insulana:}

Ten pairs of freshly emerged moths were confined a glass chimney cage, inside which a piece of cotton wool previously soaked in $10 \%$ sugar solution was suspended to be renewed every 48 hours for moths' nutrition. The top and bottom of each cage were covered with screening mesh kept in position by rubber bands for stimulating egg-laying response in the females. Eggs were deposited through the screening mesh on a piece of paper placed upper and under the cage in open Petri-dishes. In case of SBW muslin strips were held inside the chimney for eggs deposition. Cages were maintained at $\left(27 \pm 1^{\circ} \mathrm{C} \& 75 \pm 5 \% \mathrm{R}\right.$. H. $)$ and were examined daily for collecting the pieces of papers and muslin strips that contain fresh eggs.

\section{Obtaining eggs of factitious host, Angoumois grain moth:}

The eggs of Angoumois grain moth Sitotroga cerealella was used as a rearing host for Trichogramma, and was obtained from the rearing laboratory 
of Angoumois grain moth in Plant protection Research Institute, ARC, Dokki, Giza, Egypt.

Rearing of Trichogramma:

The parasitoids Trichogramma were reared on Angoumois grain moth S. cerealella eggs; eggs were glued to cards and exposed to Trichogramma adults (1 parasitoid: 10 host eggs) in glass jars (1-liter capacity). Egg cards were renewed daily to avoid super-parasitism.

\section{Experimental techniques:}

1- Mortality percentage in $P$. gossypiella and $E$. insulana eggs exposed to insecticides and Trichogramma:

Field recommended concentrations (FRCs) of the insecticides viz, Trebon, Cygron and Raner were tested initially against $P$. gossypiella and $E$. insulana eggs $<24$ hour old in laboratory and ten tested cards (200 eggs/card) of PBW and/or SBW were dipped for 15 seconds in solution of recommended dose of each insecticide while, ten cards were treated with water as untreated check (control). The treated cards were left to dry naturally for approximately one hour at room temperature. After drying, the treated cards were kept individually in glass vials $(3 \times 10 \mathrm{~cm})$ capped with cotton stoppers and maintained in an incubator at $\left(27 \pm 1^{\circ} \mathrm{C}\right.$ and $75 \pm 5 \%$ R.H.) until egg hatchability. Another ten cards (200 eggs/ card) / insect species were introduced individually in glass vials to five mated females of each Trichogramma species and incubated under the same conditions until hatchability. The numbers of hatched larvae and dead eggs for all cards treated with insecticides and/or those treated with Trichogramma species were inspected.

\section{2- Effect of exposing adult wasps of Trichogramma spp. to various} insecticides:

The adults (susceptible life stage) of Trichogramma evanescens, $T$. bactrae and $T$. brassicae were exposed to the field recommended concentrations of the aforementioned three insecticides. Free-Choice and Non-choice Tests were conducted to evaluate the acceptance of the adults' females to the less toxic insecticides.

Free Choice experiment: Fresh Sitotroga cerealella egg cards treated with the recommended field concentration of each tested insecticides and untreated cards were introduced all together to Trichogramma adult females, in the same Petri-dish sealed with parafilm to prevent adult wasps from escaping out. After the parasitized eggs turned black each treated egg card was transferred to separate tube sealed with parafilm to determine the numbers of parasitized eggs, number of emerged wasps resulted from each treated eggs with the tested insecticides.

Non-choice experiment: Fresh S. cerealella egg cards less than $24 \mathrm{~h}$ old (each contained about 150 eggs) were treated with the recommended field concentration of each tested insecticide. Treated eggs for each tested insecticide was placed separately in Petri-dish and exposed to newly emerged $T$. evanescens, $T$. bactrae and $T$. brassicae females (5 females/ Petri-dish), then sealed with parafilm . Fresh eggs treated with water only exposed to newly emerged Trichogramma spp. were used to serve as a control. 


\section{3- Residual effect of the tested insecticides to Trichogramma females}

This experiment was conducted in three steps;

Exposing Trichogramma females to treated Petri-dishes:

Ten Petri-dishes were treated with a film /each tested insecticide and left them at room temperature until dry. Five mated females of each parasite were introduced/ Petri-dish and given fresh untreated card of $S$. cerealella eggs (300 eggs/ plat). Petri-dishes were sealed with parafilm. The experiment was tested after 2 hours, 24 hours and after 8 days to determine the females' longevity and to measure the number of parasitized host eggs.

Exposing Trichogramma females to fresh treated host eggs:

Five mated females from each Trichogramma species were exposed to a fresh dry treated host eggs; i.e. cards with 300 fresh S. cerealella eggs each were dipped in the tested concentrations for five seconds, removed and left on a filter paper to dry, and then introduced to Trichogramma females in clean Petri-dish.

\section{Exposing Trichogramma females to six days residues:}

To study if the insecticides residues were still effective on host eggs after six days or not, $S$. cerealella egg cards were treated with the field recommended concentrations of the tested insecticides, then maintained at $10^{\circ} \mathrm{C}$ after drying and offered after six days to Trichogramma females. Each treated card was placed individually in Petri-dish $(5 \mathrm{~cm}$ diameter) containing five adult females ( $<24 \mathrm{~h}$ old) of Trichogramma spp. The control group was dipped in distilled water only. The treatments were checked after two hours hence daily to determine the adults' longevities, and after ten days to determine the rate of parasitism and adults' emergence. Each treatment was replicated ten times for each tested insecticide and the control.

\section{Statistical analysis}

Analysis of variance (ANOVA) was conducted on collected data using Costat (1990) computer program software. Means were compared by Duncan's multiple range test to separate the means (Snedecor \& Cochran 1980).

\section{RESULTS AND DISCUSSION}

\section{1- Mortality percentage in $P$. gossypiella and $E$. insulana eggs exposed to insecticides and Trichogramma:}

The obtained result in Table (2) showed that Trebon treatment caused the highest percentage of mortality in $P$. gossypiella eggs followed by Cygron treatment, and there were insignificant differences in mortality percentages of $P$. gossypiella eggs in both and those occurred by $T$. evanescens and $T$. brassicae. The percentage of mortality caused with these four treatments was 95.52, 93.39, 90.61 and $91.01 \%$, respectively. T. bactrae caused a moderate mortality for $P$. gossypiella eggs $(78.76 \%)$. Whereas, Raner had a relatively slight effect on $P$. gossypiella eggs, as it caused slightly percentage of mortality $(22.35 \%)$. There were significant differences between all treatments and untreated one. 
Table (2): Eggs mortalities of $P$. gossypiella and $E$. insulana caused by insecticides and Trichogramma spp.

\begin{tabular}{|c|c|c|c|c|}
\hline \multirow[b]{2}{*}{ Treatments } & \multicolumn{2}{|c|}{ P. gossypiella } & \multicolumn{2}{|c|}{ E. insulana } \\
\hline & $\begin{array}{c}\text { \%Mortality } \\
\text { (Mean } \pm \text { SD)* }\end{array}$ & Range & $\begin{array}{c}\text { \%Mortality } \\
\text { (Mean } \pm \text { SD)* }\end{array}$ & Range \\
\hline Trebon & $95.52 \pm 1.85^{\mathrm{a}}$ & $91.61-97.9$ & $78.70 \pm 7.99^{\mathrm{a}}$ & $70.05-91.67$ \\
\hline Cygron & $93.39 \pm 2.85^{a}$ & $88.65-97.78$ & $67.50 \pm 11.92^{\mathrm{DC}}$ & $41.18-85.71$ \\
\hline Raner & $22.35 \pm 6.94^{c}$ & $11.11-32.61$ & $32.82 \pm 9.44^{d}$ & $22.22-49.02$ \\
\hline T. evanescens & $90.61 \pm 8.45^{a}$ & $76.36-98.61$ & $75.10 \pm 8.44^{a b}$ & $58049-84.38$ \\
\hline T. bactrae & $78.76 \pm 7.94^{b}$ & $66.33-86.83$ & $65.72 \pm 6.33^{c}$ & $58.62-75.44$ \\
\hline T. brassicae & $91.01 \pm 4.45^{a}$ & $86.92-100$ & $70.77 \pm 8.29^{\mathrm{abc}}$ & $54.72-81.25$ \\
\hline Untreated & $9.54 \pm 3.2^{d}$ & $4-12$ & $15.18 \pm 5.45^{\mathrm{e}}$ & $8-26$ \\
\hline F value & 477.562 & & 68.096 & \\
\hline LSD (0.05\%) & 4.673 & & 7.677 & \\
\hline
\end{tabular}

${ }^{*}$ Means in the same column with the same letter are not significantly different $(P=0.05)$.

On the other hand, treatment with Trebon and $T$. evanescens led to the maximal percentage of mortality in $E$. insulana eggs $(78.70 \& 75.1 \%$, respectively). There were moderate and insignificant differences between mortality caused by Cygron and T. bactrae (67.50\&65.72\%). Raner had the least effect on the percentage of $E$. insulana eggs mortality (32.82\%) (Table 2). The resulted of Raner treatment was in agreement with those obtained by Rajendran and Hanifa (1997) who found that the incidence of Chilo sacchariphagus and the emergence of Trichogramma chilonis Ishii in sugar cane field were not affected by the insecticidal treatments.

2- Effect of exposing adults Trichogramma to various insecticides treatments:

Free-Choice and Non-choice Tests:

Effect on the percentage of parasitism:

Data presented in Table (3) indicated that in free-choice test $S$. cerealella eggs treated with insecticides were significantly less frequently parasitized by $T$. evanescens $(3.79,12.95 \& 38.25 \%$ for Trebon, Cygron and Raner, respectively) compared to $(65.96 \%)$ in the untreated eggs. Whereas, females of $T$. bactrae presented in free-choice prevented to parasite treated eggs with Trebon and Cygron (zero percentage of parasitism) and parasitized a small percentage of treated eggs with Raner $(7.53 \%)$ compared to high percentage of parasitism in untreated ones $(72.99 \%)$. Exposing $T$. brassicae females in free choice with treated and untreated eggs cleared that they preferred untreated ones and parasitized $57.65 \%$, whereas, it parasitized impotent percentages at treated S. cerealella eggs with Trebon, Cygron and Raner (3.81, 4.76\& $4.52 \%$, respectively).

On the other hand, in case of non-choice test when females of $T$. evanescens offered fresh eggs treated with Trebon, Cygron and Raner, females obligate to parasitize slightly more eggs. The percentages of parasitism were $15.4,33.37 \& 62.075$, respectively, but still declined compared to untreated one $(78.85 \%)$. Also, $T$. bactrae imposed to parasitize small number of treated eggs, as the percentages of parasitism were 5.34, 5.2, and $10.71 \%$ when fresh S. cerealella eggs treated with Trebon, Cygron and Raner were introduced, respectively, compared with higher parasitism in 
untreated eggs (92.22\%). Otherwise, exposing T. brassicae females to treated eggs had a significant great impact on parasitism as the percentage of parasitism reduced sharply from 69.66 in untreated eggs to $4.91,5.31 \&$ $4.72 \%$ in the respective insecticides. Singh and Varma (1986) found that, when $T$. brasiliensis adults were released on treated host (Corcyra cephalonica eggs). Phosalone, monocrotophos and fenvalerate inhibited parasitism by $26-64 \%$. Phosalone and fenvalerate are relatively safe for the above-mentioned natural enemies and can provide selectivity in an integrated control programs for cotton bollworms. Also, Osama and Mohamed (2012) found that $S$. cerealella fresh eggs exposed to low concentrations of glyphosate had a high parasitism viability $(85.5 \%)$ and higher percentage of $T$. evanescens adult emergence $(91.14 \%)$ that was closely similar to the untreated $89.88 \%$ and $95.59 \%$, respectively.

Table (3): Effect of exposing adults Trichogramma spp. to various insecticides in Free-Choice and Non-choice Tests.

\begin{tabular}{|l|c|c|c|c|}
\hline \multirow{2}{*}{$\begin{array}{l}\text { Treatment } \\
\text { (Recommended } \\
\text { dose) }\end{array}$} & \multicolumn{3}{|c|}{ Free-choice* $^{*}$} & \multicolumn{2}{c|}{ No-Choice* $^{*}$} \\
\cline { 2 - 5 } & Parasitism \% & Emergence \% & Parasitism \% & Emergence \% \\
\hline Trebon & \multicolumn{5}{|c|}{$T$. evanescens } \\
\hline Cygron & $3.79 \pm 3.88 \mathrm{c}$ & $62.08 \pm 6.54^{\mathrm{c}}$ & $15.40 \pm 11.49^{\mathrm{d}}$ & $57.54 \pm 18.03 \mathrm{c}$ \\
\hline Raner & $12.95 \pm 8.11 \mathrm{c}$ & $70.17 \pm 12.36 \mathrm{c}$ & $33.37 \pm 8.33 \mathrm{c}$ & $71.12 \pm 8.47^{\mathrm{b}}$ \\
\hline Untreated & $38.25 \pm 17.07 \mathrm{~b}$ & $79.88 \pm 10.71 \mathrm{~b}$ & $62.07 \pm 8.12 \mathrm{~b}$ & $83.00 \pm 8.69 \mathrm{a}$ \\
\hline F value & $65.96 \pm 10.52^{\mathrm{a}}$ & $92.01 \pm 4.11^{\mathrm{a}}$ & $78.85 \pm 7.16^{\mathrm{a}}$ & $89.58 \pm 9.76^{\mathrm{a}}$ \\
\hline LSD & 61.707 & 16.471 & 83.278 & 11.753 \\
\hline & 9.983 & 8.236 & 8.325 & 10.705 \\
\hline Trebon & \multicolumn{5}{|c|}{$T$. bactrae } \\
\hline Cygron & $0.00 \pm 0.00 \mathrm{~b}$ & - & $5.34 \pm 5.61 \mathrm{~b}$ & $69.31 \pm 11.33 \mathrm{c}$ \\
\hline Raner & $0.00 \pm 0.00 \mathrm{~b}$ & - & $5.20 \pm 4.68 \mathrm{~b}$ & $75.28 \pm 6.30 \mathrm{bc}$ \\
\hline Untreated & $7.53 \pm 18.43 \mathrm{~b}$ & $71.43 \pm 1.0 \mathrm{~b}$ & $10.71 \pm 9.41 \mathrm{~b}$ & $79.78 \pm 7.91 \mathrm{~b}$ \\
\hline F value & $72.99 \pm 16.12 \mathrm{a}$ & $88.27 \pm 7.82 \mathrm{a}$ & $92.22 \pm 3.45 \mathrm{a}$ & $91.96 \pm 6.84 \mathrm{a}$ \\
\hline LSD & 10.829 & 743.55 & 488.05 \\
\hline & 10.853 & 4.277 & 5.523 & 11.308 \\
\hline Trebon & \multicolumn{5}{|c|}{$T . \mathrm{brassicae}$} \\
\hline Cygron & $3.81 \pm 5.07 \mathrm{~b}$ & $50.00 \pm 0.00 \mathrm{c}$ & $4.91 \pm 3.44 \mathrm{~b}$ & $79.62 \pm 11.54 \mathrm{~b}$ \\
\hline Raner & $4.76 \pm 6.98 \mathrm{~b}$ & $68.06 \pm 6.37 \mathrm{~b}$ & $5.31 \pm 3.49 \mathrm{~b}$ & $68.69 \pm 16.53 \mathrm{c}$ \\
\hline Untreated & $4.52 \pm 4.36 \mathrm{~b}$ & $67.92 \pm 13.15 \mathrm{~b}$ & $4.72 \pm 5.99 \mathrm{~b}$ & $74.11 \pm 7.04 \mathrm{bc}$ \\
\hline F value & $57.65 \pm 6.54 \mathrm{a}$ & $94.29 \pm 3.42 \mathrm{a}$ & $69.66 \pm 2.95 \mathrm{a}$ & $97.33 \pm 1.15 \mathrm{a}$ \\
\hline LSD & 59.594 & 64.143 & 545.501 & 10.664 \\
\hline
\end{tabular}

${ }^{*}$ Means in the same column with the same letter are not significantly different $(P=0.05)$.

\section{Effect on percentage of emergence:}

Similar trend was recorded for the adult emergence in both free-choice and non-choice tests. Table (3) showed obvious and significant decrease in the percentage of parasitoids progeny emerged from treated host eggs compared with untreated one, except for the percentage of emergence obtained from $T$. evanescens treated with Raner in no-choice tests which decreased insignificantly from 89.58 in control to $83.0 \%$ in Raner treatment. These results are in agreement with Rajendran and Hanifa (1997) who found that application of 2000 ppm. of endosulfan and monocrotophos decreased the emergence of $T$. chilonis 
to $(43.2-50.3 \%)$ and $(34.1-42.1 \% \%)$, respectively compared with untreated control plots (78.2 and $85.8 \%)$. The obtained results of Raner treatment were in agreement with those obtained by Tipping and Burbutis (1983) who found that field-weathered carbaryl and methomyl residues did not reduce parasitoid emergence. Also, Singh and Varma (1986) found that Phosalone, monocrotophos and fenvalerate did not affect the emergence of parasitoid adults and with Gnanadhas Preetha et al (2010), who found that, Imidacloprid 17.8 SL (at the recommended dose) did not cause any adverse effects on the adult emergence of $T$. chilonis and parasitization (90.67 and $85.32 \%$, respectively).

\section{3- Residual effect of the tested insecticides to the Trichogramma females:}

Effect on the percentage of parasitism:

Table (4) cleared an obvious and significant reduction in the percentage of parasitism in all Petri-dishes' treatments compared to untreated ones. Cygron was the most sever insecticide on $T$. evanescens and $T$. bactrae, as it caused the less percentage of parasitism (12.35 and 16.16\%) for the two parasitoids, respectively. Also there were insignificant differences between the three insecticides used in case of $T$. brassicae in this treatment.. Also, the same trend occurred when exposing females of Trichogramma to the fresh insecticides residues sprayed on host eggs. Whereas, when the treated $S$. cerealella eggs held at $10^{\circ} \mathrm{C}$ for 6 days and offered to females of Trichogramma, the percentage of $T$. evanescens parasitism increased obviously from 16.88, 36.66\& 49.61 to $27.11,39.47 \& 53.66 \%$ and from $4.25,5.57 \& 10.1 \%$ to $22.99,40.58 \& 48.77 \%$ in case of $T$. bactare and from $4.02,5.59 \& 5.29 \%$ to $23.89,22.01 \& 46.2 \%$ in case of $T$. brassicae in fresh insecticides and 6 days residues, respectively.

Tipping and Burbutis (1983) stated that carbaryl residues reduced parasitism rates up to 21 days post spray. Parasitism increased over time at the lower dosage rate of methomyl.

\section{Effect on females' longevities:}

Table (4) revealed that longevity of Trichogramma spp. females presented with fresh insecticide treated Sitotroga cerealella eggs decreased significantly compared with those in untreated ones. Whereas, when the treated host eggs held for 6 days at $10^{\circ} \mathrm{C}$, and introduced to Trichogramma, females' longevities increased slightly than the fresh treated host eggs were introduced. Arunava Samanta et al. (1997) found that T. chilonis parasitoids could be safely released 3, 4 and 5 days after crop has been sprayed with alpha-cypermethrin, methomyl and quialphos, respectively. Also, Suh et al. (2000) stated that based on LC50 values, spinosad and prophenofos were the most toxic compounds to female $T$. exiguum adults, followed by lambda cyhalothrin, cypermethrin, and thiodicarb. Insecticides field- weathered for 4 to 6 days on cotton leaves showed no activity against female $T$. exiguum adults. 
Table (4): Residual effect of the tested insecticides to the Trichogramma spp. Adults

\begin{tabular}{|c|c|c|c|c|c|c|}
\hline \multirow{3}{*}{ Treatments } & \multicolumn{2}{|c|}{ Glass plate test } & \multicolumn{2}{|c|}{$\begin{array}{l}\text { Fresh insecticide residue } \\
\text { sprayed on host eggs }\end{array}$} & \multicolumn{2}{|c|}{$\begin{array}{l}6 \text { day insecticide residue } \\
\text { sprayed on host eggs }\end{array}$} \\
\hline & $\begin{array}{c}\text { parasitism } \\
\text { rate } \\
\text { (eggs/female) }\end{array}$ & $\begin{array}{l}\text { Longevity } \pm \\
\text { SD (days) }\end{array}$ & $\begin{array}{c}\text { parasitism } \\
\text { rate } \\
\text { (eggs/female) }\end{array}$ & $\begin{array}{l}\text { Longevity } \pm \\
\text { SD (days) }\end{array}$ & $\begin{array}{c}\text { parasitism } \\
\text { rate } \\
\text { (eggs/female) }\end{array}$ & $\begin{array}{l}\text { Longevity } \\
\text { SD (days) }\end{array}$ \\
\hline & \multicolumn{6}{|c|}{ T. evanescens } \\
\hline Trebon & $20.22 \pm 3.3^{b}$ & $0.39 \pm 0.07^{b}$ & $16.82 \pm 4.68^{\mathrm{d}}$ & $0.49 \pm 0.29^{b}$ & $27.77 \pm 4.24^{d}$ & $1.5 \pm 1.25^{b}$ \\
\hline Cygron & $12.35 \pm 4.35^{\mathrm{c}}$ & $0.45 \pm 0.50^{b}$ & $36.66 \pm 4.47^{c}$ & $0.59 \pm 0.39^{b}$ & $39.47 \pm 3.56^{c}$ & $1.89 \pm 1.05^{b}$ \\
\hline Raner & $17.6 \pm 4.17^{\mathrm{D}}$ & $0.69 \pm 0.47^{\mathrm{b}}$ & $49.61 \pm 4.53^{D}$ & $0.79 \pm 0.40^{\mathrm{D}}$ & $53.61 \pm 4.71^{\mathrm{D}}$ & $2.00 \pm 0.87^{\mathrm{b}}$ \\
\hline Control & $93.72 \pm 3.88^{a}$ & $4.6 \pm 1.17^{a}$ & $80.51 \pm 4.68^{a}$ & $4.6 \pm 1.1^{\mathrm{a}}$ & $82.06 \pm 4.71^{\mathrm{a}}$ & $4.6 \pm 1.17^{\mathrm{a}}$ \\
\hline \multirow[t]{2}{*}{\begin{tabular}{|l|} 
LSD \\
\end{tabular}} & 3.472 & 0.763 & 4.159 & 0.662 & 3.795 & 0.895 \\
\hline & \multicolumn{6}{|c|}{ T. bactrae } \\
\hline Trebon & $21.8 \pm 4.93^{\mathrm{b}}$ & $0.39 \pm 0.27^{b}$ & $4.25 \pm 3.27^{c}$ & $1.3 \pm 0.48^{b}$ & $22.99 \pm 4.48^{\mathrm{d}}$ & $1.4 \pm 0.70^{b}$ \\
\hline Cygron & $16.16 \pm 5.06^{c}$ & $0.54 \pm 0.50^{\mathrm{D}}$ & $5.57 \pm 3.79^{b}$ & $1.33 \pm 0.48^{b}$ & $40.58 \pm 4.29^{c}$ & $1.4 b \pm 0.52^{b}$ \\
\hline Raner & $19.85 \pm 4.29^{\mathrm{bc}}$ & $0.85 \pm 0.34^{b}$ & $10.1 \pm 3.73^{b}$ & $1.5 \pm 0.71^{\mathrm{b}}$ & $48.77 \pm 4.92 b$ & $1.5 \pm 0.71^{\mathrm{b}}$ \\
\hline Control & $78.01 \pm 4.80^{a}$ & $3.7 \pm 1.25^{\mathrm{a}}$ & $70.28 \pm 3.35^{\mathrm{a}}$ & $3.2 \pm 1.32^{a}$ & $72.62 \pm 4.84^{\mathrm{a}}$ & $3.2 \pm 1.32^{a}$ \\
\hline \multirow[t]{2}{*}{ LSD } & 4.530 & 0.764 & 3.384 & & 4.240 & 0.784 \\
\hline & \multicolumn{6}{|c|}{ T. brassicae } \\
\hline Trebon & $5.33 \pm 4.99^{b}$ & $0.47 \pm 0.45^{b}$ & $4.02 \pm 3.37^{b}$ & $0.59 \pm 0.38^{c}$ & $23.89 \pm 5.29^{c}$ & $1.5 \pm 0.71^{b}$ \\
\hline Cygron & $4.66 \pm 4.18^{\mathrm{b}}$ & $0.55 \pm 0.35^{b}$ & $5.59 \pm 3.55^{b}$ & $1.1 \pm 0.32^{b}$ & $22.01 \pm 4.95^{c}$ & $1.4 \pm 0.70^{b}$ \\
\hline Raner & $4.93 \pm 3.5^{b}$ & $0.75 \pm 0.72^{b}$ & $5.29 \pm 3.6 \mathrm{~b}$ & $1.5 \pm 0.71^{b}$ & $46.20 \pm 4.75^{\mathrm{b}}$ & $1.6 \pm 0.70^{b}$ \\
\hline Control & $74.27 \pm 7.43^{a}$ & $3.22 \pm 0.97^{a}$ & $71.94 \pm 3.32^{a}$ & $4.44 \pm 0.88^{a}$ & $74.68 \pm 3.72^{a}$ & $4.4 \pm 0.89^{a}$ \\
\hline LSD & 4.067 & 0.651 & 3.154 & 0.573 & 4.276 & 0.678 \\
\hline
\end{tabular}

*Means in the same column with the same letter are not significantly different $(P=0.05)$. 
Manal A. A. El Sharkawy
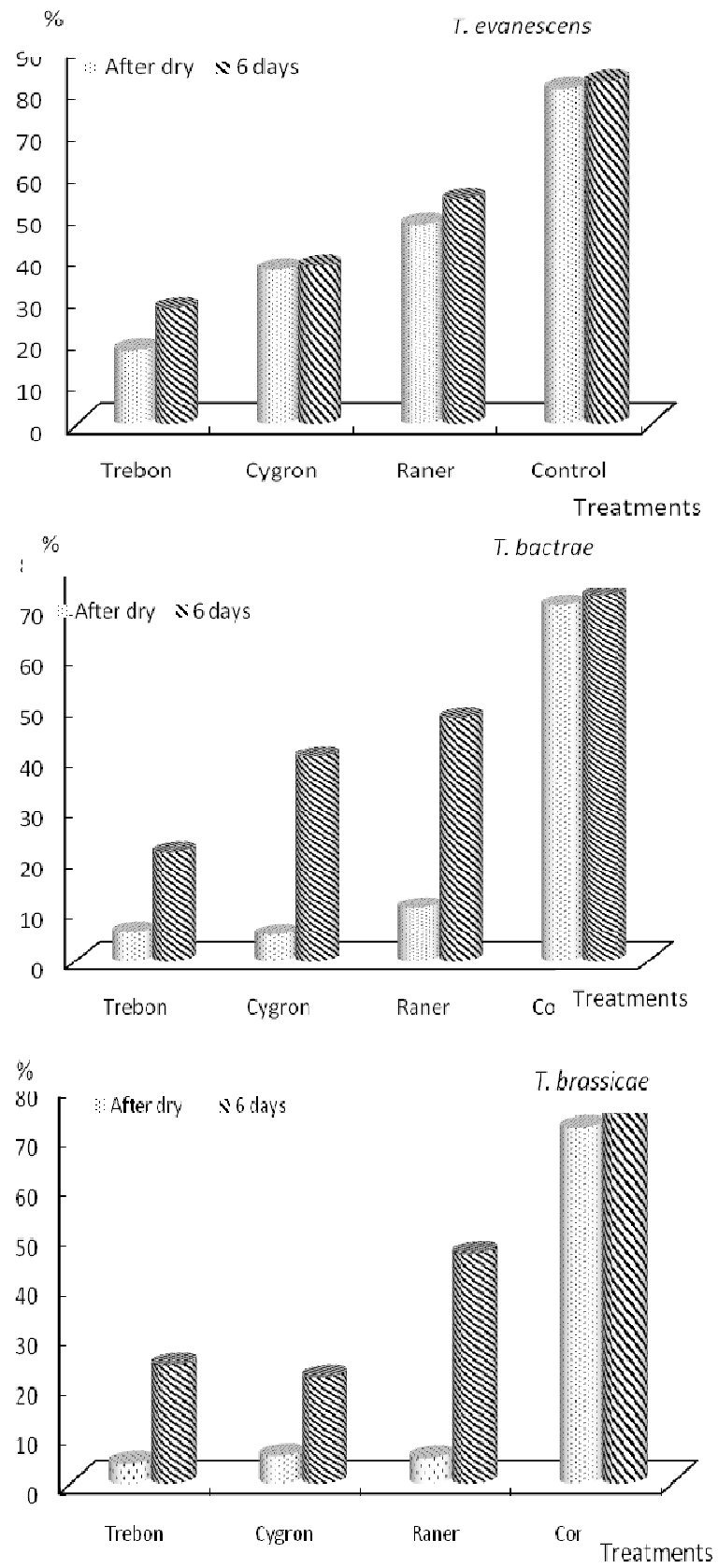

Fig (1): Residual effect of the tested insecticides to the Trichogramma females. 


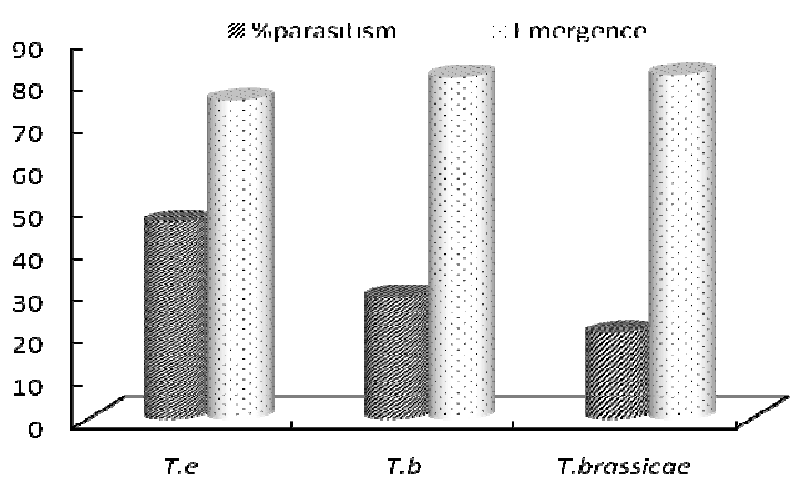

Fig (2): Effeciency of tested insecticides against Trichogramma spp.

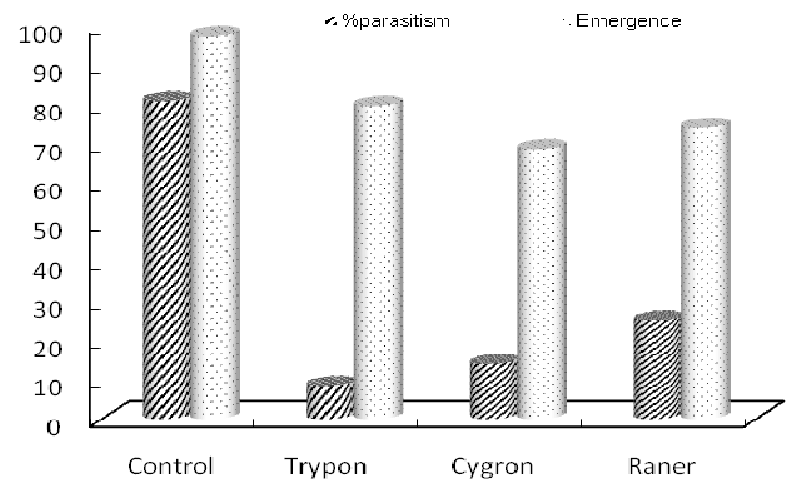

Fig (3): impact of the three tested insecticides on Trichogramma spp.

\section{CONCLUSION}

1- Trebon and Cygron could be used against $P$. gossypiella and $E$. insulana eggs as ovicidal insecticides in case of the absence of Trichogramma, whereas, it is unfavorable to use these insecticides in the presence of Trichogramma.

2- Trichogramma. evanescens was the less effected species to insecticides followed by $T$. bactrae, while, $T$. brassicae was the most effected species to insecticides.

3- Both Trebon and Cygron were relatively harmful to the tested parasitoids and therefore, could not be used in combination with Trichogramma releases, whereas, Raner was the harmless insecticide. 


\section{REFERENCES}

Abbas, M.S.T.(2004): Successful applications Trichogramma evanescens (West.) for controlling certain insect pests in Egypt. 1 Arab Conference of Applied Biological pest control, Cairo, Egypt, 5-7 April 2004: 148(Abstract).

Abd El-Hafez, Alia; A. G. Metwally and M. R. A. Saleh (1982): Rearing pink bollworm Pectinophora gossypiella (Saund.) on kidney bean diet in Egypt (Lepidoptera: Gelechiidae). Res. Bull., Fac. Agric., Zagazig Univ., April, No.576, 10pp.

Antoon, J.M.L., T. Jan, J.F. Joan and C.L. Joop (2006): Releases of Parsoitoids (Ceranisus spp.) as biological control agents of western flower thrips (Frankiliella occidentalis) in experimental glasshouses. Bulletin of Insectol. 59(2): 85-97.

Arunava Samanta; A. K. Das; A. Chowdhury; A. K. Somchoudhury and P. Roy (1997): In Advances in IPM for horticultural crops. Proceedings of the First National Symposium on Pest Management in Horticultural crops: environmental implications and thrusts, Bagalore, India, 15-17 October, 257-265.

Bigler, F. (1984): Mass production and field application of Trichogramma maidis Pintureau \& Voegele against the European corn borer in Switzerland. AbstractVol. XVII. Intern. Cong. Ent., Hamburg, Germany, pp: 788.

Costat Statistical Software. (1990): Microcomputer program analysis Version 4.20.Berkeley, CA: Cohort Software.

David Pimentel (2005): Enviromental and economic costs of the application of pesticides

Degrande, P.E., P.R. Reis, G.A. Carvalho and L.C. Belarnino(2002): Metodologia para avaliar o impacto de Pesticidas Sobr Inimigos Naturais, pp: 71-93. In: Parra. J.R.P., P.S.M. Botelho, B.S. CorreaFerreira, e J.M.S. Bento, (Eds.), Controle biologico no Brasil. Manole, Barueri, Sao Paulo, Brazil.

Devotto, L., E. Cisternas, R. Carrillo and M. Gerding (2008): Non-target effects of Dalaca pallens Blanchard control examined through principal response curves: A guild approach in southern Chile. Chilean. J. Agric. Res., 68: 228-237.

Gnanadhas Preetha1, Thiyagarajan Manoharan1, Johnson Stanley and asthakutty Kuttalam1 (2010): Impact of Chloronicotinyl Insecticide, Imidacloprid on egg, egg-larval and larval parasitoids under laboratory conditions Journal of Plant Protection Research 50 (4) 535-540.

King, E. G., L. F. Bouse, D. L. Bull, W. A. Dickerson, W. J. Lewis, P. Liapis, J. D. Lopez, R. K. Morrison and Phillips, J. R. (1984): Potential of management of Heliothis spp. In cotton by augmentative releases of Trichogramma pretiosum, pp. 232-236. . In Proceedings, Beltwide Cotton Production Research Conference. National Cotton Council, Memphis, TN. 
Osama A. El Sebai and Mohamed F. El-Tawil (2012): Side-Effect of Certain Herbicides on Egg Parasitoid Trichogramma evanescens (West.): (Hymenoptera: Trichogrammatidae) Academic Journal of Entomology 5 (1): 1-10.Primarily in the UNITED STATES. Environment, Development and Sustainability 7: 229-252.

Rajendran, B. and A. M. Hanifa (1997): Effect of insecticides on the emergence of Trichogramma chilonis Ishii. In sugar cane field. Cooperative-Sugar., 29 (1): 27-30.

Singh P. P., and G. C. Varma, (1986): Comparative toxicities of some insecticides to Chrysoperla carnea (Chrysopidae: Neuroptera: Hymenoptera) and Trichogramma brasiliensis (Trichogrammatidae: Hymenoptera), two arthropod natural enemies of cotton pests. Agric. Ecosys. Environ., 5: 23-30.

Singh S.P., Jalali S.K. (1994): Trichogrammatids. Technical Bulletin No. 9, Project Directorate of Biological Control, Bangalore, 93 pp.

Smith, S.M. (1996):Biological control with Trichogramma: advances, successes and potential for their use. Ann. Rev. Entomol., 41: 375406.

Snedecor, G. W. and W. G. Cochran (1980): Statistical Methods, $2^{\text {nd }}$ Ed. The lowa State Univeristy Press, Ames, lowa, pp. 318.

Stark, J.D., Vargas, R. and Banks, J.E. (2007): Incorporating ecologically relevant measures of pesticide effect for estimating the compatibility of pesticides and biocontrol agents. J. econ. Ent., 100: 102, 7-1032.

Suh, C. P., D. B. Orr, and J. W. Van Duyn (2000): Effect of Insecticides on Trichogramma exiguum (Trichogrammatidae: J. ymenoptera) Preimaginal Development and Adult Survival Econ. Entomol. 93(3): 577-583.

Tipping, P. W. and P. P. Burbutis (1983): Some effects of pesticide residues on Trichogramma nubilale (Hym.: Trichogrammatidae) J. Econ. Entomol. 76: 892-896.

Tuhan, N. C., A. D. Pawar \& R. S. Arora (1987): Use of Trichogramm brasiliensis Ashmead against cotton bollworms in Srigangangar, Rajasthan ,India. J. Adv. Zool. 8(2): 131-4. 


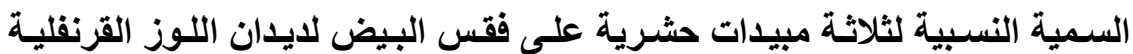

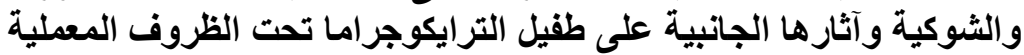

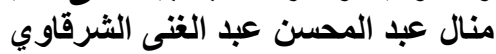
معهد بحوث وقاية النباتات ـ مركز البحوثٍ الزراعية

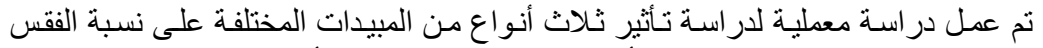

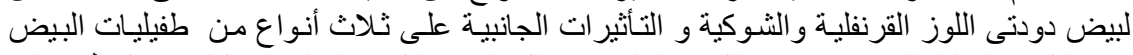

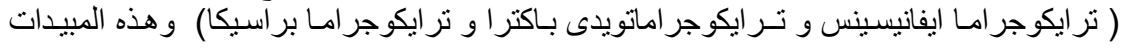

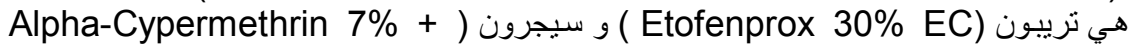
(Flufenoxuron 3\% EC

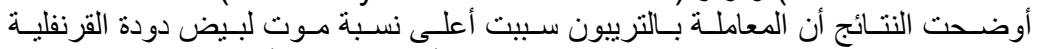

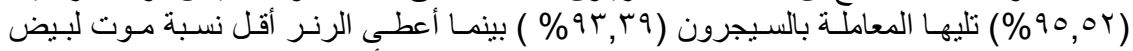

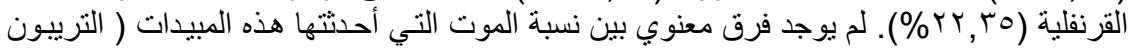

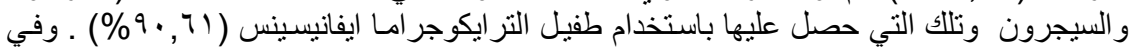

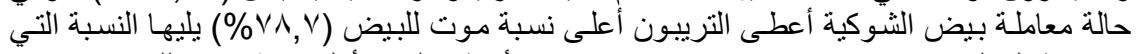

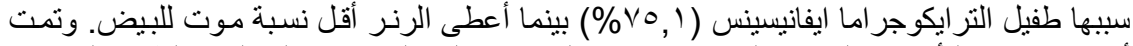

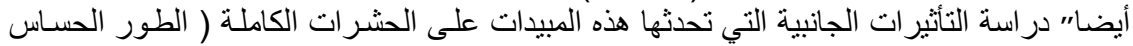

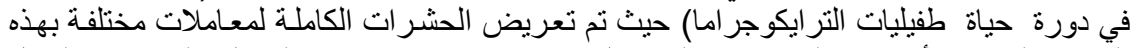

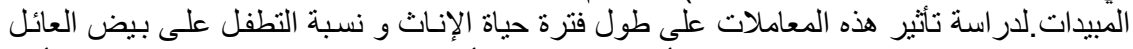

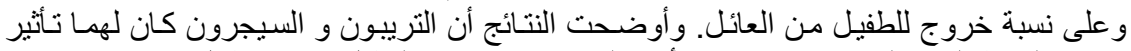

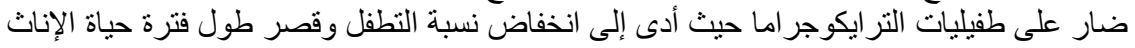

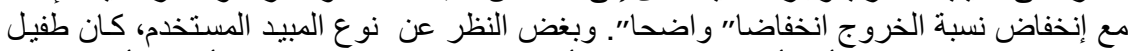

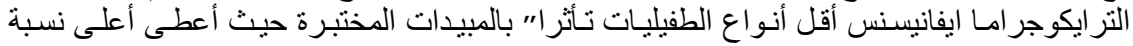

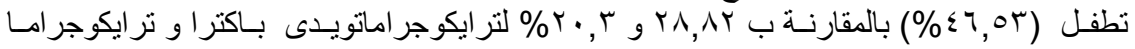

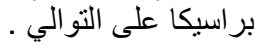

